\title{
STATUS BESI PADA PASIEN PENYAKIT GINJAL KRONIK \\ YANG SEDANG MENJALANI HEMODIALISIS \\ DI BLU RSU.Prof.Dr.R.D KANDOU MANADO
}

\author{
${ }^{1}$ Cynthia Ombuh \\ ${ }^{2}$ Linda Rotty \\ ${ }^{3}$ Stella Palar
}

Bagian Ilmu Penyakit Dalam Fakultas Kedokteran Universitas Sam Ratulangi Manado

\section{Email: cynthiaombuh@yahoo.com}

\begin{abstract}
Background: Chronic Kidney Disease (CKD) is kidney damage that occurred during the three months or more with a glomerular filtration rate less than 60 $\mathrm{ml} / \mathrm{men} . / 1,73 \mathrm{~m} 2$. One complication that often occurs in patients with CKD is anemia. Anemia in CKD can be caused by several factors such as EPO deficiency, Iron Deficiency, etc. and one of the parameters commonly examined in patients with CKD who are undergoing hemodialysis is composed of iron status Serum Iron (SI), TIBC, Transferrin Saturation, Ferritin.

Objective: Looking iron status in CKD patients

Methods: The study design was a descriptive look at the medical records of the patients who are undergoing hemodialysis with purposive sampling technique.

Results: In patients with CKD undergoing hemodialysis anemia. Anemia all experienced that often caused by the presence of erythropoietin deficiency. But there are also caused by iron deficiency from a status marked where the iron transferrin saturation $<20 \%$. There was also found an increase in ferritin $>400 \mathrm{ng} /$ $\mathrm{ml}$ caused by the presence of an infection such as anemia or chronic disease can also be caused due to frequent blood transfusions. Treatment for iron overload in patients with CKD, especially regular hemodialysis patients who undergo repeated blood transfusions can be re-utilization by the use of ESA, anemia in CKD caused by deficiency erythropoietin.ESA therapy may also be given.

Conclusion: Based on the results of research in the department of hemodialysis room Prof.Dr.RD Kandou obtained all patients with chronic kidney disease decreased hemoglobin, and Serum Iron which fell by $40 \%$, the normal $60 \%$, and ferritin were increased by $46.7 \%$, that no data $53.3 \%$ and TIBC were decreased by $80 \%$, as much as $20 \%$ of normal and Transferrin Saturation fell by $6.7 \%$, which increased by $3.3 \%$ and as much as $90 \%$ of normal.
\end{abstract}

Keywords: CKD, iron status 


\begin{abstract}
ABSTRAK
Latar Belakang : Penyakit Ginjal Kronik (PGK) adalah kerusakan ginjal yang terjadi selama atau lebih tiga bulan dengan laju filtrasi glomerulus kurang dari 60 $\mathrm{ml} / \mathrm{men} . / 1,73 \mathrm{~m} 2$. Salah satu komplikasi yang sering terjadi pada pasien PGK adalah anemia. Anemia pada PGK dapat disebabkan oleh beberapa faktor seperti: Defisiensi EPO, Defisiensi Besi, dll dan salah satu parameter yang biasa diperiksa pada pasien PGK yang sedang menjalani hemodialisis adalah status besi yang terdiri dari Serum Iron (SI), TIBC, Saturasi Transferin, Feritin.
\end{abstract}

Tujuan : Melihat Status besi pada pasien PGK

Metode : Desain penelitian adalah deskriptif dengan melihat data rekam medik para pasien yang sedang menjalani hemodialisis dengan teknik purposive sampling.

Hasil : Pada pasien PGK yang menjalani hemodialisis semuanya mengalami anemia.Anemia yang sering terjadi disebabkan oleh karena adanya defisiensi eritropoetin. Namun ada juga yang disebabkan oleh defisiensi besi yang ditandai dari pemeriksaan status besi dimana saturasi transferin $<20 \%$. Ada juga didapatkan peningkatan Feritin > $400 \mathrm{ng} / \mathrm{ml}$ yang disebabkan oleh karena adanya infeksi seperti pada anemia penyakit kronis atau juga bisa disebabkan karena seringnya transfusi darah. Penatalaksanaan untuk kelebihan zat besi pada pasien PGK terutama pasien hemodialisis reguler yang mengalami transfusi darah berulang dapat dire-utilisasi dengan pemakaian ESA, anemia pada PGK yang disebabkan oleh dekfisiensi eritopoetin juga dapat diberikan terapi ESA.

Kesimpulan : Berdasarkan hasil penelitian di ruangan hemodialisis di RSUP Prof.Dr.R.D Kandou didapatkan semua pasien penyakit ginjal kronik mengalami penurunan $\mathrm{Hb}$,dan Serum Iron yang menurun sebanyak $40 \%$, yang normal sebanyak $60 \%$, dan Feritin yang meningkat sebanyak 46,7\%, yang tidak ada data sebanyak 53,3\% dan TIBC yang menurun sebanyak $80 \%$, yang normal sebanyak $20 \%$ dan Saturasi Transferin yang menurun sebanyak 6,7\% yang meningkat sebanyak 3,3\% dan yang normal sebanyak $90 \%$.

Kata Kunci: PGK, Status Besi

Gagal ginjal adalah suatu keadaan klinis yang ditandai dengan penurunan fungsiginjal yang ireversibel, pada suatu derajat yang memerlukan terapi pengganti ginjal yang tetap, berupa dialisis atau transplantasi ginjal. ${ }^{1}$ Gagal ginjal biasanya dibagi menjadi dua kategori yang luas yaitu kronik dan akut. Penyakit ginjal kronik merupakan perkembangan gagal ginjal yang progresif dan lambat (biasanya berlangsung beberapa tahun), mengakibatkan tertumpuknya sisa-sisa metabolik yang toksik serta gangguan keseimbangan air, elektrolit, dan asam basa. ${ }^{2}$ Sebaliknya, gagal ginjal akut terjadi dalam beberapa hari atau minggu. ${ }^{3}$

Insiden penyakit ginjal di negara-negara berkembang diperkirakan sekitar 40-60 kasus perjuta penduduk per tahun ${ }^{1}$. Data United State Renal Data System (URSDS) menunjukkan bahwa jumlah gagal ginjal terminal (GGT) yang menjalani dialysis di Amerika Serikat pada akhir tahun 1991 terdapat 142.488 pasien dialisis,90\% dari populasi tersebut menjalani terapi hemodialisis.Di Indonesia pada tahun 1999, PT 
Asuransi Kesehatan (ASKES) menanggung sekitar 3000 penderita gagal ginjal terminal yang menjalani hemodialisis. ${ }^{4}$

Imroatul Ulya, Suryanto (2007) menyatakan pernyataan tentang "Penyakit Ginjal Kronik ( PGK ) merupakan perkembangan gagal ginjal yang progresif dan lambat, dimana ginjal kehilangan kemampuan untuk mempertahankan volume dan komposisi cairan tubuh dengan nilai glomerular filtration rate (GFR ) 25\% - 10\% dari nilai normal. Transplantasi atau HD digunakan sebagai terapi pengganti untuk menggantikan fungsi ginjal yang memburuk". 3

Hemodialisis merupakan terapi pengganti ginjal yang dilakukan dengan mengalirkan darah ke dalam suatu tabung ginjal buatan (dialiser ) yang bertujuan untuk mengeliminasi sisa-sisa metabolisme protein dan koreksi gangguan keseimbangan elektrolit antara kompartemen darah dengan kompartemen dialisat melalui membran semipermiabel. ${ }^{4}$ Tapan (2004) menyatakan bahwa "Penderita PGK yang sedang melakukan HD akan menderita anemia". Anemia merupakan komplikasi PGK yang sering terjadi, bahkan dapat terjadi lebih awal dibandingkan komplikasi PGK lainnya dan pada hampir semua pasien PGTA. Anemia sendiri juga dapat meningkatkan risiko morbiditas dan mortalitas secara bermakna dari PGK. ${ }^{5}$ Menurut data dari NHANES III, diperkirakan 13,5 juta memiliki creatinin clearance $(\mathrm{CrCl}) \leq 50 \mathrm{ml} /$ menit dan kejadian anemia yang ditandai dengan kadar hemoglobin $<11 \mathrm{~g} / \mathrm{dl}$ sebesar 800.000 orang. ${ }^{6}$ Pada pasien pradialisis dengan laju filtrasi glomerulus (LFG) kurang dari $60 \mathrm{ml} / \mathrm{mnt} / 1,73 \mathrm{~m} 2$ (PGK stadium3 5), kejadian anemia dengan kadar hemoglobin $(\mathrm{Hb})$ kurang atau sama dengan $12 \mathrm{~g} / \mathrm{dl}$ adalah sebesar 50\%. ${ }^{7}$ Penyebab utama anemia pada PGK diperkirakan adalah karena defisiensi relatif dari eritropoetin (EPO). Penyebab lainnya yang ikut berperan terhadap terjadinya anemia pada PGK yaitu defisiensi besi, asam folat atau vitamin B12, inflamasi kronik, perdarahan, racun metabolik yang menghambat eritropoesis dan hemolisis baik oleh karena bahan uremik ataupun sebagai akibat dari hemodialisis. ${ }^{8}$ Oleh karena banyaknya kasus PGK yang terjadi dan adanya penelitian sebelumnya mengenai defisiensi besi pada PGK, maka peneliti tertarik untuk melakukan penelitian tentang "Status Besi pada pasien Penyakit Ginjal Kronik yang sedang menjalani hemodialisis di RSU BLU Prof.Dr.R.D Kandou Manado"

\section{METODE PENELITIAN}

Desain penelitian ini bersifat deskriptif dengan metode cross sectional. Penelitian dilakukan di Bagian Ilmu Penyakit Dalam RSU BLU Prof.Dr.R.D Kandou Manado.Penelitian dilakukan dalam bulan November-Desember.Populasi dari penelitian ini adalah seluruh penderita PGK yang dirawat inap di bagian Ilmu Penyakit Dalam RSU BLU Prof.Dr.R.D Kandou Manado dan penderita PGK yang sedang menjalani hemodialisis di RSU BLU Prof.Dr.R.D Kandou. Penelitian ini menggunakan data rekam medik di bagian Ilmu Penyakit Dalam BLU RSUP Prof.Dr.R.D Kandou Manado dan literatur-literatur yang berhubungan dengan penelitian ini. Variabel penelitian ini adalah:Hemoglobin, Serum Iron, TIBC ( Total Iron Binding Capacity), Feritin, Saturasi Transferin, Pemberian ESA, Transfusi darah. Penelitian ini dilakukan dengan mengumpulkan data-data kasus pasien yang telah didiagnosis gagal ginjal kronik dengan menggunakan teknik purposive sampling. Kemudian melihat dan mencatat status besi para pasien PGK yang sedang menjalani hemodialisis.

\section{HASIL PENELITIAN}

Berdasarkan penelitian deskriptif yang dilaksanakan di bagian hemodialisis BLU RSUP Prof.Dr.R.D Kandou Manado, didapatkan jumlah penderita PGK yang sedang 
menjalani hemodialisis sebanyak 92 orang. Dari 92 penderita PGK yang menjalani hemodialisis hanya terdapat 30 orang saja yang diketahui status besinya, yang terdiri dari 18 laki-laki dan 12 perempuan. Data ini kemudian diolah beradasarkan variabel yang telah ditetapkan.

Tabel 1. Distribusi sampel beradasrkan Hb

\begin{tabular}{cccc}
\hline Jenis Kelamin & \multicolumn{2}{c}{ Hb } & Persentase (\%) \\
& Menurun & Normal & \\
\hline P & 12 & - & 40 \\
L & 18 & - & 60 \\
Total & 30 & - & 100
\end{tabular}

Tabel 2 Distribusi sampel berdasarkan serum iron

$\begin{array}{ccc}\text { Serum Iron } & \text { Frekuensi (n) } & \text { Persentase (\%) } \\ \text { Menurun } & 12 & 40 \\ \text { Normal } & 18 & 60 \\ \text { Meningkat } & - & - \\ \text { Total } & 30 & 100\end{array}$

Tabel 3. Distribusi sampel berdasarkan TIBC

$\begin{array}{ccc}\text { TIBC } & \text { Frekuensi (n) } & \text { Persentase (\%) } \\ \text { Menurun } & 24 & 80 \\ \text { Normal } & 6 & 20 \\ \text { Meningkat } & - & - \\ \text { Total } & 30 & 100\end{array}$

Tabel 4. Distribusi sampel berdasarkan saturasi transferin

$\begin{array}{ccc}\text { Saturasi Transferin } & \text { Frekuensi (n) } & \text { Persentase (\%) } \\ \text { Menurun } & 2 & 6.7 \\ \text { Normal } & 27 & 90 \\ \text { Meningkat } & 1 & 3.3 \\ \text { Total } & 30 & 100\end{array}$


Tabel 5. Distribusi sampel berdasarkan feritin

\begin{tabular}{ccc}
\hline Feritin & Frekuensi (n) & Persentase (\%) \\
\hline Meningkat & 14 & 46.7 \\
No Data & 16 & 53.3 \\
\hline Total & 30 & 100 \\
\hline
\end{tabular}

Tabel 6. Hubungan antara status besi dengan transfusi darah

\begin{tabular}{cccccc}
\hline \multirow{2}{*}{ Transfusi Darah } & \multicolumn{4}{c}{ ST } & \\
\cline { 2 - 4 } & turun & Normal & meningkat & Persentase & $P$ \\
\hline Tidak Transfusi & $2(7 \%)$ & $13(43 \%)$ & $1(3 \%)$ & $53 \%$ & \\
$<5$ kali/thn & 0 & $11(37 \%)$ & 0 & $37 \%$ & 0.572 \\
5-10 kali/thn & 0 & $3(10 \%)$ & 0 & $10 \%$ & \\
Total & $2(7 \%)$ & $27(90 \%)$ & $1(3 \%)$ & $100 \%$ & \\
\hline
\end{tabular}

Tabe1 7. Hubungan antara status besi dengan terapi ESA

\begin{tabular}{|c|c|c|c|c|c|}
\hline \multirow[b]{2}{*}{ Terapi ESA } & \multicolumn{3}{|c|}{ ST } & \multirow[b]{2}{*}{ Persentase } & \multirow[b]{2}{*}{$P$} \\
\hline & turun & Normal & meningkat & & \\
\hline Terapi & 0 & $19(63 \%)$ & 0 & $63 \%$ & \\
\hline Non Terapi & $2(7 \%)$ & $8(27 \%)$ & $1(3 \%)$ & $37 \%$ & 0.056 \\
\hline Total & $2(7 \%)$ & $27(90 \%)$ & $1(3 \%)$ & $100 \%$ & \\
\hline
\end{tabular}

\section{PEMBAHASAN}

Berdasarkan hasil penelitian deksriptif, pasien PGK yang sedang menjalani hemodialisis di BLU RSUP Prof.Dr.R.D Kandou Manado berjumlah 92 orang. Dalam penelitian ini standarisasi yang di ambil untuk menetukan status besi pasien PGK yaitu berdasarkan pemeriksaan Serum Iron (SI), TIBC, Feritin dan Saturasi Transferin. Data inilah yang diolah berdasarkan variabel yang telah ditetapkan sebelumnya.

Dari hasil penelitian kali ini didapatkan bahwa hampir seluruh pasien PGK memiliki $\mathrm{Hb}$ yang rendah. The European Best Practice Guidelines untuk pelaksanaan anemia pada pasien-pasien PGK mengatakan bahwa batas bawah hemoglobin normal adalah $11.5 \mathrm{gr} / \mathrm{dl}$ pada wanita, $13.5 \mathrm{gr} / \mathrm{dl}$ pada laki-laki dibawah atau sama dengan 70 tahun dan $12.0 \mathrm{gr} / \mathrm{dl}$ pada laki-laki diatas 70 tahun. ${ }^{9}$ The National Kidney Foundation's Kidney Dialyis Outcomes Quality Initiative (K/DOQI) merekomendasikan anemia pada pasien PGK jika kadar hemoglobin $<11 \mathrm{gr} / \mathrm{dl}$ (hematokrit 33\%) pada wanita premenopause dan pasien prepubertas dan $<12 \mathrm{gr} / \mathrm{dl}$ (hematokrit <37\%) pada laki-laki dewasa dan wanita postmenopause. $^{9}$ 
Fatmawati (2008) menyatakan bahwa "Anemia pada PGK muncul ketika klirens kreatinin turun kira-kira $40 \mathrm{ml} / \mathrm{mnt} / 1,73 \mathrm{~m}^{2}$ dari permukaan tubuh. Anemia akan lebih berat apabila fungsi ginjal menjadi lebih buruk lagi, tetapi apabila penyakit ginjal telah mencapai stadium akhir, anemia relatif akan menetap. Anemia pada PGK terutama diakibatkan oleh berkurangnya produksi eritropoetin (EPO). EPO merupakan hormon yang dapat merangsang sumsum tulang untuk memproduksi sel darah merah. Anemia merupakan kendala yang cukup besar bagi upaya mempertahankan kualitas hidup pasien PGK. Anemia yang terjadi dapat meningkatkan angka morbilitas dan mortalitas". ${ }^{10}$

Anemia pada PGK juga dapat disebabkan oleh defisiensi besi. Anemia defisiensi besi dapat didiagnosa dengan menggunakan pemeriksaan laboratorium status besi konvensional seperti serum iron(SI), Total Iron Binding Capacity (TIBC), saturasi transferin, dan serum feritin. ${ }^{9}$ Anemia Defisiensi besi ditamdai dengan saturasi transferin menurun dan kadar feritin berkurang. ${ }^{11}$ Walmsey et al. Menyatakan secara berurutan perubahan laboratoris pada defisiensi besi sebagai berikut : 1.Penurunan simpanan besi, 2.Penurunan feritin serum, 3.Penurunan besi serum disertai meningkatnya transferin serum, 4.Peningkatan Red Cell Distribution Width (RDW), 5.Penurunan Mean Corpuscular Volume (MCV), 6.Penurunan Hemoglobin. ${ }^{12}$ Anemia defisiensi besi ialah tahap defisiensi besi yang berat yang ditandai dengan kadar feritin serum serta hemoglobin yang menurun. ${ }^{13}$

Pada penelitian kali ini didapatkan bahwa PGK pada umumnya terjadi anemia. Namun anemia pada PGK dapat terjadi karena berbagai faktor, namun yang sering didapatkan yaitu anemia yang disebabkan karena defisiensi dari eritropoetin (EPO) dan penyebab lainnya yaitu adanya defisiensi zat besi. Dari data yang dikumpulkan sebanyak 30 pasien PGK yang sedang menjalani hemodialisis mengalami anemia yang terlihat dari hasil pemeriksaan $\mathrm{Hb}$ yang di bawah nilai normal. Dan pada pemeriksaan status besi antara lain Serum Iron (SI), Feritin, TIBC dan Saturasi Transferin didapatkan hasil Serum Iron yang menurun sebanyak 12 orang $(40 \%)$ dan serum iron yang normal sebanyak 18 orang $(60 \%)$. Feritin yang meningkat sebanyak 14 orang $(46.7 \%)$ dan feritin yang tidak ada data sebanyak 16 orang (53.3\%). TIBC yang menurun sebanyak 24 orang (80\%) dan TIBC yang normal sebanyak 6 orang (20\%). Saturasi Transferin yang menurun sebanyak 2 orang $(6.7 \%)$, meningkat 1 orang (3.3\%), dan normal sebanyak 27 orang (90\%). TIBC yang menurun pada pasien PGK disebabkan karena meningkatnya feritin, dapat terjadi pada anemia penyakit kronis yang terjadi inflamasi. ${ }^{10}$ Namun pada pasien hemodialisis regular dapat mengalami anemia defisiensi zat besi karena kehilangan darah. ${ }^{9}$ Didasari keadaan cadangan besi akan timbul defisiensi besi yang terdiri atas 3 tahap dimulai dari tahap yang paling ringan yaitu tahap pralaten dimana terjadi penurunan feritin serum kurang dari $12 \mathrm{ug} / \mathrm{L}$ dan komponen yang lain seperti TIBC, SI $<$ ST masih dalam batas normal, kedua tahap laten dimana terjadi penurunan feritin serum, besi serum, saturasi transferin, TIBC meningkat > $390 \mathrm{ug} / \mathrm{L}$, ketiga tahap anemia defisiensi besi dimana kadar feritin serum serta hemoglobin yang turun, TIBC meningkat $>410 \mathrm{ug} / \mathrm{dl} .{ }^{15}$

Wish JB (2006) menyatakan bahwa pada pasien PGK dengan hemodialisi sering ditemui keadaan dimana ST rendah dan feritin serum tinggi karena terjadi defisiensi besi fungsional atau blokade transpor besi dari organ retikuloendotelial. ${ }^{14}$ Bila sering mengalami transfusi darah pasien biasanya beresiko untuk mengalami kelebihan zat besi yang dapat ditunjukkan oleh kadar feritin serum yang tinggi. ${ }^{9}$ Feritin merupakan tempat penyimpanan zat besi terbesar dalam tubuh. Fungsi feritin adalah sebagai penyimpanan zat besi terutama di dalam hati, limpa, dan sumsum tulang. Feritin serum menyatakan cadangan protein dalam tubuh dan juga merupakan protein fase akut yang nilainya akan meningkat pada keadaan inflamasi akut maupun kronis. Kadar feritin serum tinggi yang ekstrim >2000 ng/ml biasanya menandakan adanya kelebihan besi yang juga dikenal dengan hemosiderosis. Kebanyakan laporan kasus mengenai kelebihan besi dijumpai pada masa belum digunakannya ESA, ketika transfusi darah lebih sering digunakan dalam mengatasi anemia. ${ }^{14}$ Pada pasien hemodialisis penumpukan zat besi sering terjadi 
di hepar, ketika fungsi eritroid sumsum tulang sangat rendah, sedangkan penumpukan zat besi dalam jumlah lebih sedikit dijumpai pada jantung, ginjal dan pancreas. ${ }^{14}$ Penatalaksanaan untuk kelebihan zat besi pada pasien PGK terutama pasien hemodialisis reguler yang mengalami transfusi darah berulang dapat dire-utilisasi dengan pemakaian ESA, anemia pada PGK yang disebabkan oleh dekfisiensi eritopoetin juga dapat diberikan terapi ESA adapun parameter yang perlu dievaluasi pada pemberian ESA yaitu hemoglobin $(\mathrm{Hb})$ atau hematokrit, indeks sel darah merah, jumlah retikulosit, parameter status besi tubuh yaitu serum iron (SI), Total Iron Binding Capacity (TIBC), saturasi transferin, dan feritin serum. Karena pemberian terapi ESA memerlukan besi yang cukup.

Dua bentuk keadaan yang dapat terjadi dengan pemberian terapi ESA yaitu :1.True Iron Deficiency terjadi selama pemberian ESA jangka panjang disebabkan adanya perpindahan progresif besi dari cadangan simpan besi tubuh menuju eritron, 2. Functional atau Relative Iron Deficiency terjadi pada keadaan cadangan simpanan besi tubuh yang normal (atau bahkan meningkat) tetapi suplai besi ke dalam eritron tidak adekuat untuk memenuhi kebutuhan sel progenitor eritroid. Adanya ketidakseimbangan suplai besi terhadap eritropoesis sumsung tulang ditandai dengan rendahnya saturasi transferin $(<20 \%) .{ }^{16}$ Tessitore et al (2001) menyatakan "ESA merangsang sumsum tulang meningkatkan eritropoesis dengan tujuan meningkatkan jumlah hemoglobin, sementara besi merupakan salah satu bahan pembentuk hemoglobin, jadi apabila besi yang tersedia tidak mencukupi maka terapi ESA tidak bermanfaat dan pasien akan tetap dalam status anemia". ${ }^{14}$

\section{Simpulan}

Berdasarkan hasil penelitian yang dilakukan di Bagian Ilmu Penyakit Dalam BLU RSUP Prof.Dr.R.D Kandou Manado di ruangan hemodialisa, dapat disimpulkan bahwa semua penderita penyakit ginjal kronik yang diteliti memiliki nilai $\mathrm{Hb}$ yang rendah yang bisa disebabkan oleh karena adanya defisiensi eritropoetin atau defisiensi besi,asam folat dan vitamin B12. Serum Iron (SI) didapatkan menurun sebanyak $40 \%$ dan yang normal sebanyak $60 \%$, Feritin didapatkan meningkat sebanyak $46.7 \%$ dan yang tidak ada data sebanyak $53.3 \%$, Feritin yang meningkat disebabkan oleh karena adanya transfusi darah yang sering atau menunjukkan adanya infeksi.TIBC didapatkan menurun sebanyak $80 \%$ dan yang normal sebanyak 20\%, Saturasi Transferin didapatkan Saturasi Transferin menurun sebanyak $6.7 \%$, yang meningkat sebanyak $3.3 \%$ dan yang normal sebanyak $90 \%$. Terapi anemia paling banyak diberikan terapi ESA yaitu 19 orang.

\section{Ucapan Terima Kasih}

Dan kepada semua pihak baik secara langsung maupun tidak langsung telah membubuhkan ide, gagasan pada penulis sehingga penulis dapat menyelesaikan artikel ini.

\section{DAFTAR PUSTAKA}

1. Suwitra K.Penyakit Ginjal Kronik. Dalam: Sudoyo AW et al, eds. Buku Ajar IlmuPenyakit Dalam Jilid I. Edisi Keempat. Jakarta: Pusat Penerbitan Ilmu Penyakit Dalam FKUI; 2007. h.570-573h

2. Baradero M,SPC,MN,Dayrit M,Siswadi Y.Klien Gangguan Ginjal:Penerbit Buku Kedokteran EGC.Jakarta.2009 
3. Wilson LM. Anatomi dan Fisiologi Ginjal dan Saluran Kemih. Dalam: Price SA,Wilson LM, eds.Patofisiologi Volume 2.Edisi 6. Jakarta: Penerbit BukuKedokteran EGC; 2003. h.865, 867-868, 912, 917-918, 965.

4. Silviani Dewi,Adityawarman,Dwianasari Lieza.Hubungan Lama Periode Hemodialisis dengan status albumin penderita gagal ginjal kronik di unit hemodialisis RSUD.Prof.Dr.Margono Soekarjo Purwokerto.Mandala of Health volume 5.Nomor 2.Purwokerto.2011

5. Macdougal IC, Walker R, Provenzano R, Alvaro F, Locay HR, Nader PC, et al. Corrects anemia in patients with chronic kidney disease not on dialysis: results of randomized clinical trial. Clin J Am Soc Nephrol 2008;3: 337-47.

6. Hsu C, Mcculloch CE, Curhan GC.Epidemiology of anemia associated with chronic renal insuficiency among adults in the Unites States: results from the third national health and nutrition examination survey. J Am Soc Nephrol 2002;13:50410 .

7. Mcclellan WM, Aronoff SL, Bolton WK.The prevalence of anemia in patients with chronic kidney disease. Curr Med Res Opin 2004;20:1501-10.

8. Seguchi C, Shima T, Misaki M, Takarada Y, Okazaki T. Serum erythropoietin concentration and iron status in patients on chronic hemodialysis. Clin.Chem 1992;38(2):199-203.

9. Yendriwati.Status besi pada penderita gagal ginjal kronik dalam menetukan diagnosa anemia.Jurnal Universitas Sumatera Utara.2008.

10. Noorazizah.Perbandingan kadar Fe/TIBC dan jumalh eritrosit pada pasien hemodialisa pada pasien PGK.Jurnal UNIMUS.2010

11. Wirawan,R,Diagnosis Anemia.MKI,1995. 45 (12) 713-21

12. Walmsey,R.N,Wakinson LR.,Cain HJ.,Plasma Iron:Case in chemical pathology a diagnostic approach, $4^{\text {th }}$ edition, $1999.238-46$

13. Lee,G.R.,The anemia of chronic disorders.In Lee GR eds Wintrobe's Clinical Haemotology $9^{\text {th }}$ edition.Malvern,Pennyslvania:Lea and Febriger,1993.840-50

14. Dalimunthe N,Peningkatan Nilai Parameter Status Besi Reticulocyte Hemoglobin Equivalent setelah pemberian suplemen besi intravena pada pasien hemodialisis reguler.Medan:Universitas Sumatera Utara.2012.

15. Muhammad A,Stanipar O,Penentuan Defisiensi Besi Anemia Penyakit Kronis Menggunakan Peran Indeks sTfR-F.Yogyakarta:Bagian Patologi Klinik Universitas Gadjah Mada,2003.

16. Gazolla M, Mercuriali F, Bruganara C. Useof recombinant human erytrophoetin outside the setting of uremia.Blood, 1997;89(12):4248-67 